\title{
Decreased Indicators of Lung Injury with Continuous Positive Expiratory Pressure in Preterm Lambs
}

\author{
ALAN H. JOBE, BORIS W. KRAMER, TIMOTHY J. MOSS, JOHN P. NEWNHAM, AND \\ MACHIKO IKEGAMI \\ Division of Pulmonary Biology, Cincinnati Children's Hospital, Cincinnati, Ohio 45229, U.S.A.
}

\begin{abstract}
Continuous positive airway pressure (CPAP) is being used clinically to avoid mechanical ventilation of preterm infants as a strategy to minimize lung injury. There is little experimental information about how CPAP might minimize lung injury after preterm birth. We induced preterm labor in antenatal glucocorticoid-treated sheep carrying twins at $133 \mathrm{~d}$ gestation with an inhibitor of progesterone synthesis. The lambs delivered spontaneously approximately $2 \mathrm{~d}$ later and were randomized to three groups: no ventilation $(n=4)$, conventional mechanical ventilation to a target $\mathrm{PCO}_{2}$ of $40 \mathrm{~mm} \mathrm{Hg}(n=5)$, or CPAP using a bubble CPAP device set to deliver $5 \mathrm{~cm} \mathrm{H}_{2} \mathrm{O}$ pressure $(n=6)$. The CPAP lambs breathed without distress and maintained $\mathrm{PCO}_{2}$ values of approximately $60 \mathrm{~mm} \mathrm{Hg}$. At $2 \mathrm{~h}$ of age, the lungs of the CPAP lambs held $74 \pm 4 \mathrm{~mL} / \mathrm{kg}$ air at $40 \mathrm{~cm} \mathrm{H}_{2} \mathrm{O}$ pressure, which was more than the $60 \pm 3 \mathrm{~mL} / \mathrm{kg}$ for the ventilated lambs $(p<0.05)$. Lymphocyte and monocyte numbers in alveolar washes were equivalent in the unventilated, ventilated, and
\end{abstract}

\section{ABSTRACT}

CPAP lambs. However, no neutrophils were found in the unventilated lambs, and the ventilated lambs had 6.6 times more neutrophils in alveolar washes than did the CPAP lambs $(p<$ 0.05). The cells in alveolar wash from CPAP lambs contained less hydrogen peroxide than did the cells from ventilated lambs $(p<0.05)$. In this model in preterm lambs CPAP results in lower indicators of acute lung injury than does mechanical ventilation during the first 2 h of life. (Pediatr Res 52: 387-392, 2002)

$\quad$ Abbreviations
BPD, bronchopulmonary dysplasia
CPAP, continuous positive airway pressure
PIP, peak inspiratory pressure
RDS, respiratory distress syndrome
Sat PC, saturated phosphatidylcholine
TNF- $\alpha$, tumor necrosis factor- $\alpha$

The outcomes for preterm infants with RDS have improved during the last $30 \mathrm{y}$ by innovations in neonatal care that include mechanical ventilation for infants, antenatal glucocorticoids, and surfactant treatments (1-3). Before these therapies were commonly available, Gregory et al. (4) described the use of a simple device to provide CPAP as a way to maintain lung gas volumes in preterm infants with RDS. The use of CPAP as a primary therapy for RDS has become less frequent in many centers because of mechanical ventilators, although it is used to facilitate extubation and to treat apnea of prematurity (5). The major pulmonary morbidity resulting from the treatment of RDS is BPD, which is frequent in infants with birth weights

Received December 18, 2001; accepted April 2, 2002.

Correspondence and reprint requests: Alan H. Jobe, M.D., Ph.D., Cincinnati Children's Hospital, Division of Pulmonary Biology, 3333 Burnet Avenue, Cincinnati, OH 452293039, U.S.A.; e-mail: alan.jobe@chmcc.org

Supported by grant HD-12714 from the National Institute of Child Health and Human Development. The devices used for bubble CPAP were provided by Fisher-Pykel, Auckland, NZ.

DOI: 10.1203/01.PDR.0000025341.25481.42 less than $1 \mathrm{~kg}(6)$. The frequency of BPD varies among neonatal units, and its occurrence has been associated by multivariant analysis with intubation and ventilation on the first day of life $(7,8)$. In several epidemiologic studies, avoidance of mechanical ventilation and the increased use of CPAP have been associated with a decrease in $\operatorname{BPD}(9,10)$. Therefore, there is a renewed interest in the use of CPAP to facilitate the initiation of spontaneous breathing and to decrease the need for mechanical ventilation of preterm infants.

BPD develops in very preterm infants because lung injury is superimposed on an immature lung in the saccular stage of development $(11,12)$. The initial inflammation and subsequent repair processes interfere with normal lung development and result in a variable pattern of alveolar simplification, fibrosis, and chronic inflammation $(13,14)$. We found that ventilation of preterm lambs from birth initiates an inflammatory response characterized by recruitment of neutrophils to the lungs, increased hydrogen peroxide, and proinflammatory cytokine expression (15). The mechanisms by which CPAP might protect the preterm lung from injury have not been investigated in the human or in animal models. Therefore, we evaluated the effects 
of CPAP in comparison with mechanical ventilation on the lungs of preterm lambs.

\section{METHODS}

Animal model. The animal protocols were approved by the animal use committees of the Western Australia Department of Agriculture and The Cincinnati Children's Hospital Research Foundation. We tried to use CPAP to assist spontaneous breathing in preterm lambs delivered by cesarean section, but the lambs did not breathe spontaneously. To better prepare the lambs to breathe, we treated Merino ewes carrying twins at 132-134 d gestational age with an inhibitor of progesterone synthesis (epostane; Sanobi-Synthelabo, Malvern, PA, U.S.A.) and $6 \mathrm{mg}$ betamethasone (Celestone Chronodose; ScheringPlough, New South Wales, Australia) to induce preterm labor $(16,17)$. The epostane $(20 \mathrm{mg})$ was dissolved in $70 \%$ ethanol and given to the ewe by i.v. injection (17). The lambs delivered spontaneously approximately 36 to $50 \mathrm{~h}$ later. We cut the cord and sampled cord arterial blood when possible. The lambs randomized to study without breathing received a lethal dose of $50 \mathrm{mg} / \mathrm{kg}$ pentobarbital by i.v. injection immediately after birth and before breathing was initiated. The other lambs were dried, intubated with a cuffed $4.5-\mathrm{mm}$ endotracheal tube, and randomized to CPAP or mechanical ventilation. CPAP was delivered using a disposable bubble CPAP device provided by Fisher-Paykel (Auckland, New Zealand) using humidified 40\% oxygen and with the CPAP set to $5 \mathrm{~cm} \mathrm{H}_{2} \mathrm{O}$. Mechanical ventilation was with $40 \%$ humidified oxygen using a Bourns BP-100 infant ventilator using a rate of 40 breaths/min, an inspiratory time of $0.7 \mathrm{~s}$, a positive end-expiratory pressure of $4 \mathrm{~cm} \mathrm{H}_{2} \mathrm{O}$, and a peak inspiratory pressure adjusted to target a $\mathrm{PCO}_{2}$ of $40 \mathrm{~mm} \mathrm{Hg}$ (18). Tidal volumes were monitored continuously with Florian monitors (Acutronic Medical Systems AG, Hirzel, Switzerland). The animals on CPAP received no sedation, and the ventilated animals received ketamine (10 $\mathrm{mg} / \mathrm{kg}$, i.m.) as needed to suppress spontaneous breathing. Umbilical arterial catheters were used to sample blood, and body temperature was maintained with radiant warmers and heat lamps.

Processing of lungs. After $2 \mathrm{~h}$ of spontaneous breathing with CPAP or mechanical ventilation, lambs were given $100 \%$ oxygen, and, concurrently with a lethal dose of pentobarbital, the endotracheal tube was clamped for 3 min to permit oxygen absorption (18). The thorax of the lamb was opened, the lungs were inflated with air to $40 \mathrm{~cm} \mathrm{H}_{2} \mathrm{O}$ pressure for $1 \mathrm{~min}$, and the maximum lung volume was recorded (18). The pressure measured with a water manometer was sequentially lowered to 20 , $15,10,5$ and $0 \mathrm{~cm} \mathrm{H}_{2} \mathrm{O}$, and lung volumes were recorded after $30 \mathrm{~s}$ at each pressure. Volumes were corrected for the compliance of the system and were expressed as milliliters per kilogram body weight. Tissue from the right lower lobe was immediately frozen in liquid nitrogen for RNA isolation. An alveolar wash of the left lung was performed with $0.9 \% \mathrm{NaCl}$ at $4^{\circ} \mathrm{C}$, and the lavage was repeated five times (19). Alveolar wash samples were pooled, and aliquots were saved for measurement of Sat PC, total protein, cell number, and differential count.
Alveolar wash samples were centrifuged at $500 \times g$ for 10 min, and the pellet was suspended in PBS. Cells were stained with trypan blue and counted. Differential cell counts were performed on cytospin preparations after staining with DiffQuick (American Scientific Products, San Diego, CA, U.S.A.). The activation state of the alveolar wash cells recovered by centrifugation was assessed without stimulation by measuring hydrogen peroxide using an assay based on the oxidation of ferrous iron $\left(\mathrm{Fe}^{2+}\right)$ to ferric iron $\left(\mathrm{Fe}^{3+}\right)$ by hydrogen peroxide (Bioxytech $\mathrm{H}_{2} \mathrm{O}_{2}-560$ Assay; 0XIS International, Portland, OR, U.S.A.) (20). The total protein in the alveolar wash was measured (21), and wet to dry weight ratios were determined after drying pieces of the right lower lobe at $80^{\circ} \mathrm{C}$ for $96 \mathrm{~h}$.

Cytokine mRNA. Total RNA was isolated from tissue from the right lower lobe and from cell pellets of the alveolar wash samples by guanidinium thiocyanate-phenol-chloroform extraction. Ribonuclease protection assays were performed with total RNA from lung tissue and cell pellets (22). Briefly, RNA transcripts of ovine interleukins (IL-1 $\beta$, IL-6, IL-8, IL-10), TNF- $\alpha$, and ovine ribosomal protein L32 as a reference RNA were synthesized with $\left[{ }^{32} \mathrm{P}\right]$ uridine triphosphate (Life Sciences Products, Boston, MA, U.S.A.) using SP6 or T7 polymerase (Ribonuclease Protection Assay 111; Ambion, Austin, TX, U.S.A.). Aliquots of $10 \mu \mathrm{g}$ of RNA were incubated with excess radiolabeled probes for cytokines and $\mathrm{L} 32$ at $55^{\circ} \mathrm{C}$ for $18 \mathrm{~h}$, and single-stranded RNA was digested with RNase A/RNase $\mathrm{Ti}$ (Ambion). Protected fragments were electrophoresed on a $6 \%$ polyacrylamide-urea sequencing gel and visualized by autoradiography. Densities of the protected bands were quantified on a PhosphorImager (Molecular Dynamics Inc., Sunnyvale, CA, U.S.A.), using ImageQuant Software (Molecular Dynamics).

Saturated phosphatidylcholine. Sat PC was isolated from chloroform-methanol (2:1) extracts of alveolar washes by neutral alumina column chromatography after exposure of lipid extracts to osmium tetroxide (23). Sat PC was quantified by phosphorus assay (24).

Histologic scoring of lung tissue. The right upper lobe was inflation fixed with $10 \%$ formalin maintained at $30 \mathrm{~cm} \mathrm{H}_{2} \mathrm{O}$ pressure. Paraffin tissue sections of 5 - $\mu \mathrm{m}$ thickness, stained with hematoxylin and eosin, were graded for the degree of inflammation by scoring three sections from each animal in a blinded fashion (25). The score was 0 if there were no inflammatory cells in tissue or airspaces; 1 if a few cells were identified; 2 if moderate cell infiltration was present; and 3 if there were a large number of inflammatory cells in airspaces and tissue. Airspaces and tissue were assessed separately. Average scores were calculated for each animal.

Data analysis. Results are presented as mean \pm SEM. ANOVA followed by the Tukey multiple comparison procedure was used for comparisons of the three groups. Two-tailed unpaired $t$ tests were used for two group comparisons. Significance was accepted at $p<0.05$.

\section{RESULTS}

Lung function. There were no differences in cord blood $\mathrm{pH}$ for the three groups of animals (Table 1). The CPAP animals 
Table 1. Description of animals

\begin{tabular}{lccc}
\hline \multicolumn{1}{c}{ Variable } & No-ventilation & $\begin{array}{c}\text { Mechanical } \\
\text { ventilation }\end{array}$ & CPAP \\
Number & 4 & 5 & 6 \\
Male/female & $3 / 1$ & $3 / 2$ & $2 / 4$ \\
Body weight $(\mathrm{kg})$ & $2.95 \pm 0.30$ & $3.10 \pm 0.13 \dagger$ & $2.60 \pm 0.13$ \\
Cord blood pH & $7.42 \pm 0.01^{*}$ & $7.44 \pm 0.02^{*}$ & $7.44 \pm 0.01^{*}$ \\
\hline
\end{tabular}

* Cord blood for pH available for 3 of 4 no-ventilation, 3 of 5 ventilated, and 5 of 6 CPAP animals.

$\dagger$ Different from CPAP group, $p<0.05$

were smaller than the animals randomized to mechanical ventilation. One of the control lambs was heavily meconium stained, and another lamb was not successfully intubated at birth and was asphyxiated. These animals are not included in the analyses. The lambs on bubble CPAP initiated spontaneous ventilation after birth, had minimal retractions, were not apneic, and maintained a mean respiratory rate of approximately 50 breaths $/ \mathrm{min}$. The $\mathrm{PCO}_{2}$ at $15 \mathrm{~min}$ of age was $70 \pm 2 \mathrm{~mm} \mathrm{Hg}$, and the $\mathrm{PCO}_{2}$ decreased to approximately $60 \mathrm{~mm} \mathrm{Hg}$ for the rest of the 2-h study (Fig. 1). The low $\mathrm{pH}$ values reflected the elevated $\mathrm{PCO}_{2}$ values in the CPAP group. The $\mathrm{PCO}_{2}$ values for the ventilated animals averaged $40 \mathrm{~mm} \mathrm{Hg}$ by design, and these ventilated lambs had higher $\mathrm{pH}$ values than the animals treated with CPAP. The ventilated lambs received $24 \pm 2 \mathrm{~cm}$ $\mathrm{H}_{2} \mathrm{O}$ PIP at $30 \mathrm{~min}$ of age and $19 \pm 1 \mathrm{~cm} \mathrm{H}_{2} \mathrm{O}$ PIP at $2 \mathrm{~h}$ of age. The calculated mean airway pressures were $12 \mathrm{~cm} \mathrm{H}_{2} \mathrm{O}$ at $30 \mathrm{~min}$ and $11 \mathrm{~cm} \mathrm{H}_{2} \mathrm{O}$ at $2 \mathrm{~h}$ of age. The average tidal volume for the $2 \mathrm{~h}$ of mechanical ventilation was $9.6 \pm 0.3 \mathrm{~mL} / \mathrm{kg}$, and
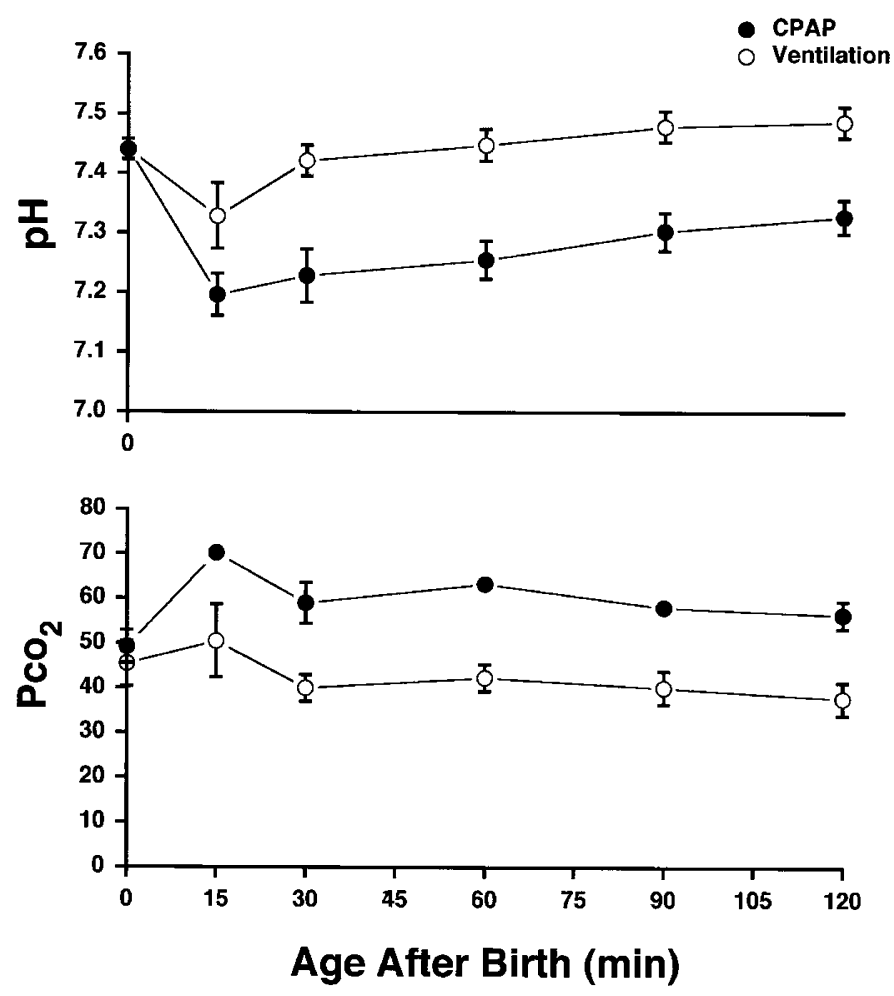

Figure 1. Blood $\mathrm{pH}$ and $\mathrm{PCO}_{2}$ values for the cord blood and for $120 \mathrm{~min}$ after birth. The $\mathrm{pH}$ and $\mathrm{PCO}_{2}$ values were different between the ventilation and CPAP groups at all times except for the cord blood values at 0 time $(p<0.05)$. SEM indicators are contained within the data points when no SEM is given on the graphs. the tidal volume did not vary with age after birth. Oxygenation in both groups of lambs receiving $40 \%$ oxygen was quite variable and not different between groups. The average value for the CPAP group was $75 \pm 13 \mathrm{~mm} \mathrm{Hg}$ and $107 \pm 44 \mathrm{~mm}$ $\mathrm{Hg}$ for the ventilated group at $2 \mathrm{~h}$.

Pressure-volume curves and surfactant. The deflation limbs of the pressure-volume curves for the lambs treated with CPAP or mechanical ventilation were parallel, but the lung volumes were higher for the CPAP animals (Fig. 2). The amount of Sat PC recovered by alveolar wash was $5.2 \pm 1.0$ $\mu \mathrm{mol} / \mathrm{kg}$ for the unventilated lambs, $7.7 \pm 0.9 \mu \mathrm{mol} / \mathrm{kg}$ for the CPAP animals, and $7.1 \pm 1.8 \mu \mathrm{mol} / \mathrm{kg}$ for the ventilated animals. The amounts of Sat PC in alveolar washes were not different for the CPAP and ventilated groups, but both these groups had higher values than the unventilated lambs $(p<$ 0.05).

Indicators of injury. There were no differences in lung wet to dry weight ratios or total protein recovered by alveolar washes among the lambs that were not ventilated, the mechanically ventilated lambs, and the CPAP lambs (Table 2). The numbers of lymphocytes and monocytes in alveolar lavages also were similar for the three groups (Fig. $3 A$ ). However, neutrophils were not detected in alveolar washes from the unventilated animals and were 6.6 times higher in the mechanically ventilated lambs than in the CPAP lambs (Fig. 3B). The cells from the alveolar washes of the unventilated lambs and the CPAP lambs contained similar amounts of hydrogen peroxide, and the hydrogen peroxide content was higher for the mechanically ventilated lambs than for the CPAP lambs. The mRNA expression in lung tissue for IL- $1 \beta$, IL-6, and IL-8 was

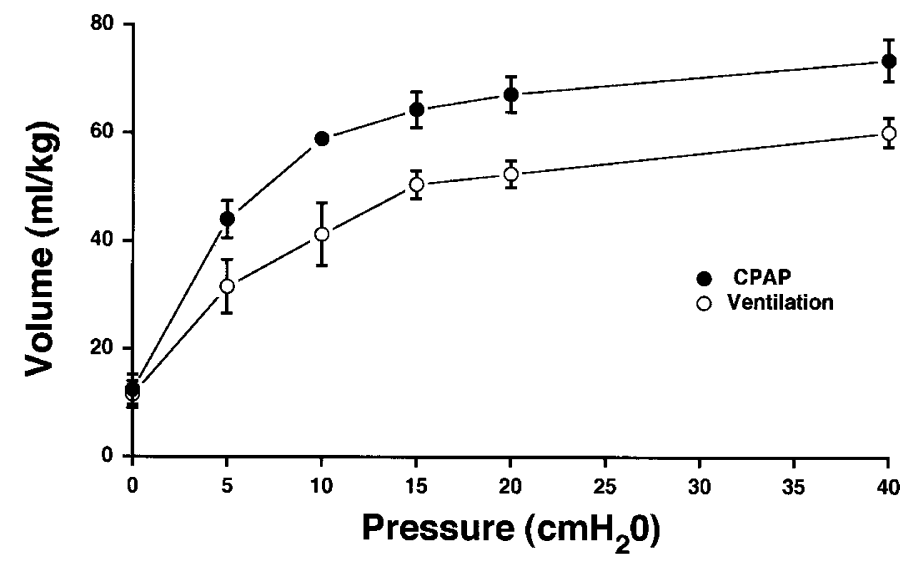

Figure 2. Deflation pressure-volume curves for the CPAP lambs and the ventilated lambs. All volumes between 10 and $40 \mathrm{~cm} \mathrm{H}_{2} \mathrm{O}$ pressure are higher for the CPAP lungs than for the ventilated lungs $(p<0.05)$. 
Table 2. Indicators of lung injury

\begin{tabular}{|c|c|c|c|}
\hline Variable & $\begin{array}{c}\text { No- } \\
\text { ventilation }\end{array}$ & $\begin{array}{c}\text { Mechanical } \\
\text { ventilation }\end{array}$ & CPAP \\
\hline Lung Wet/dry weight (g/g) & $8.64 \pm 0.49$ & $7.56 \pm 0.38$ & $7.75 \pm 0.35$ \\
\hline Protein in alveolar washes $(\mathrm{mg} / \mathrm{kg})$ & $45.7 \pm 8.5$ & $33.0 \pm 5.6$ & $43.6 \pm 2.9$ \\
\hline IL- $1 \beta$ & $1.0 \pm 0.24$ & $1.20 \pm 0.22$ & $1.04 \pm 0.23$ \\
\hline IL-6 & $1.0 \pm 0.18$ & $1.36 \pm 0.29$ & $1.27 \pm 0.35$ \\
\hline IL-8 & $1.0 \pm 0.11$ & $1.48 \pm 0.23$ & $1.37 \pm 0.28$ \\
\hline IL-6 & $1.0 \pm 0.12$ & $1.85 \pm 0.34$ & $1.09 \pm 0.23$ \\
\hline IL-8 & $1.0 \pm 0.25$ & $2.95 \pm 0.83$ & $1.56 \pm 0.63$ \\
\hline
\end{tabular}
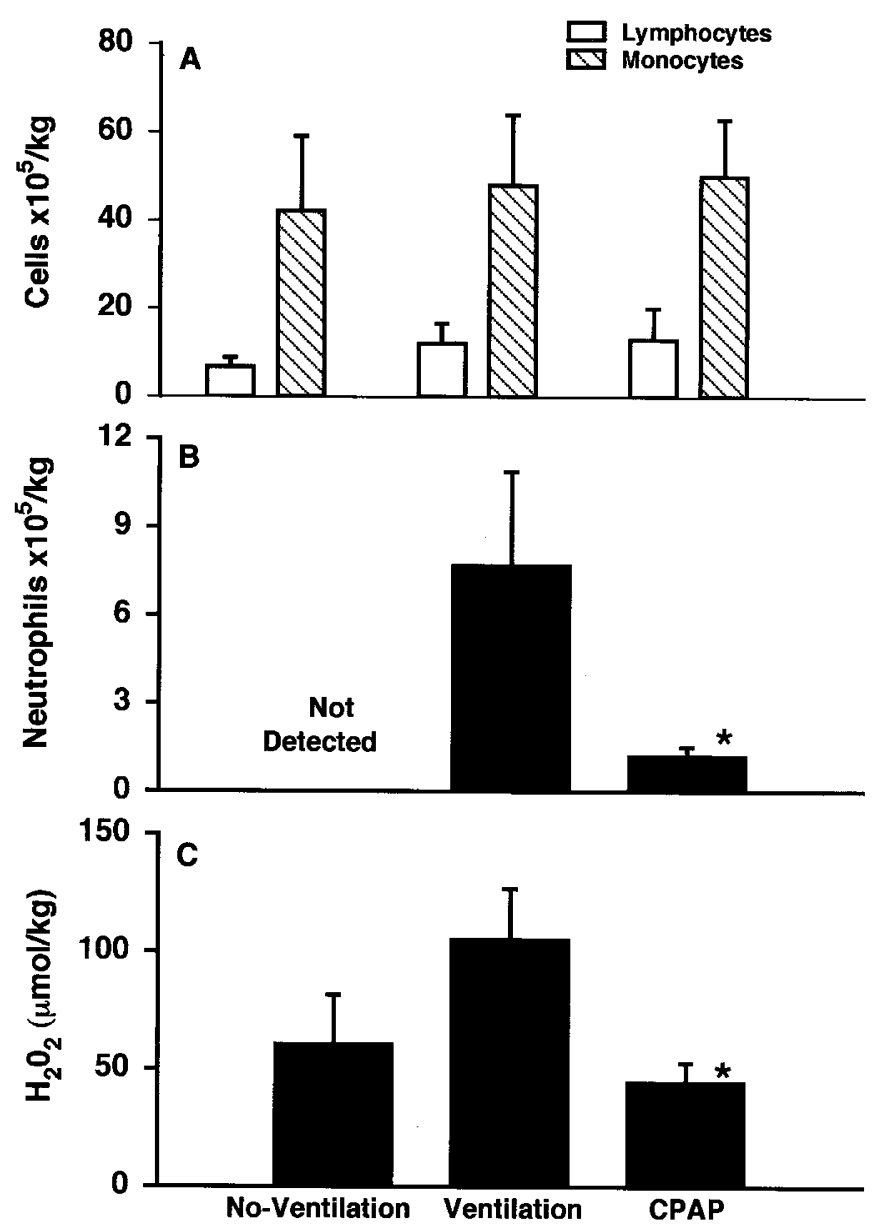

Figure 3. Lymphocytes and monocytes in alveolar washes $(A)$, neutrophils in alveolar washes $(B)$, and hydrogen peroxide $\left(\mathrm{H}_{2} \mathrm{O}_{2}\right)$ in cells from alveolar washes $(C)$. Lymphocyte and monocyte numbers were equivalent for the three groups. There were fewer neutrophils in the alveolar washes of the CPAP lambs than the mechanically ventilated lambs. Less $\mathrm{H}_{2} \mathrm{O}_{2}$ was in the cells from the alveolar washes of the CPAP lambs than the ventilated lambs $(p<0.05 v s$ ventilation).

not different among the groups (Table 2), and no mRNA was detected for IL-4, IL-10, or TNF- $\alpha$ in the lung tissue. There also was no significant increase in IL- $1 \beta$, IL- 6 , or IL- 8 mRNA in cell pellets recovered from the alveolar washes for the CPAP or mechanically ventilated lambs relative to the unventilated control lambs, although values tended to be higher for the mechanically ventilated lambs. There was not severe edema or cellular infiltrates in any of the lungs. The mean histologic score of $1.2 \pm 0.2$ for the ventilated lungs indicating a few inflammatory cells were consistently found in the tissue and airspaces was increased relative to the value of $0.8 \pm 0.1$ for the unventilated lungs ( $p<0.2$ by $t$ test). The CPAP lambs had a histologic score of $0.9 \pm 0.1$, which was not different from the unventilated lungs.

\section{DISCUSSION}

CPAP is used primarily in conjunction with surfactant treatments to decrease the need for mechanical ventilation or to facilitate early extubation from mechanical ventilation $(5,26)$. CPAP will increase the functional residual capacity of the lung and may increase respiratory drive. The avoidance of intubation in the delivery room and the use of CPAP were associated with a decrease in BPD in several clinical reports $(9,10,27)$. By multivariant analyses, intubation and mechanical ventilation of preterm infants is the major predictor of subsequent BPD (8). The mechanisms responsible for the possible effects of CPAP to decrease BPD have not been evaluated. A possible mechanism is the avoidance of aggressive initiation of gas exchange with high tidal volumes and inadvertent hyperventilation that occurs in intubated infants $(28,29)$. CPAP also protects the infant from standard mechanical ventilation and inadvertent over or under ventilation as well as airway injury and colonization from the endotracheal tube. These benefits are consistent with the concepts that BPD results from repetitive inflammatory stresses on the preterm lung $(30,31)$. The initiation of ventilation, especially with high tidal volumes, results in the recruitment of activated granulocytes to the preterm sheep lung (32). Mechanical ventilation of the surfactanttreated preterm baboon lung results in persistent elevations of inflammatory cells and proinflammatory cytokines in the lungs (30). The effects of CPAP on neonatal transition or on inflammation in the lung have not been evaluated.

We failed in initial attempts to study CPAP in the preterm sheep because the lambs would not breathe consistently after delivery by cesarean section. Attempts at pharmacologic stimulation at delivery with intravascular injections of catecholamines, cortisol, and caffeine did not help. Therefore, we thought that the process of labor and spontaneous delivery might prepare the lamb to breathe spontaneously. To mimic the clinical situation we gave antenatal betamethasone and an inhibitor of progesterone synthesis to induce preterm labor (16, 
17). The ewes delivered without incident, and the preterm lambs had normal cord $\mathrm{pH}$ values and began breathing spontaneously.

We intubated the lambs to avoid problems with secretions and position-dependent delivery of the CPAP to assure effective delivery of the CPAP. We used a commercial version of the bubble CPAP system used by Dr. Jen Wung at Columbia (33). We used $5 \mathrm{~cm} \mathrm{H}_{2} \mathrm{O}$ pressure because most clinical reports use this pressure, although there is minimal information about the optimal pressures for CPAP in infants $(4,9,26)$. The chests of the lambs visibly vibrated using a gas flow of $10 \mathrm{~L} / \mathrm{min}$. The lambs breathed comfortably and were not distressed despite their self-regulation of $\mathrm{PCO}_{2}$ to approximately $60 \mathrm{~mm} \mathrm{Hg}$. The lambs did not try to normalize $\mathrm{PCO}_{2}$ values and thus had a respiratory acidosis. Infants managed by avoidance of intubation in the delivery room and with CPAP also have higher $\mathrm{PCO}_{2}$ values than is generally considered normal in the first minutes to hours of life $(26,27)$. We limited this initial experiment to $2 \mathrm{~h}$ because we did not know how long the animals would survive on CPAP and because indicators of lung injury are measurable within $2 \mathrm{~h}$ of preterm birth (34). Longer experiments might better resolve differences between lambs supported with mechanical ventilation and CPAP.

We used conventional ventilation with a target $\mathrm{P}_{\mathrm{CO}_{2}}$ of 40 $\mathrm{mm} \mathrm{Hg}$ for the ventilated lambs. This $\mathrm{PCO}_{2}$ was chosen as a normal value because we did not know how the CPAP lambs would regulate $\mathrm{PCO}_{2}$. The animals had RDS because they were ventilated with PIPs of $19 \pm 2 \mathrm{~cm} \mathrm{H}_{2} \mathrm{O}$ at $2 \mathrm{~h}$ of age and had low pool sizes of Sat PC (35). The tidal volumes given to the lambs were higher than generally recommended for preterm infants, but this tidal volume is no more injurious than highfrequency oscillation in preterm lambs (36). The higher tidal volume is needed to normalize $\mathrm{PCO}_{2}$ in lambs in part because these animals have higher dead space than infants. Interesting comparisons for the future would be to compare lung injury in ventilated and CPAP lambs using equivalent $\mathrm{PCO}_{2}$ targets or mean airway pressures. The CPAP lambs and mechanically ventilated lambs had the same low alveolar pool sizes of surfactant lipid. This measurement indicates equivalent degrees of lung maturation in both groups. The difference in the amount of surfactant lipid between the unventilated lambs and the other groups resulted from secretion with breathing (37).

Despite equivalent surfactant pool sizes, the CPAP group had fewer neutrophils, less hydrogen peroxide, and larger lung gas volumes than did the mechanically ventilated lambs. There were no differences in proinflammatory cytokine expression between the ventilated groups, although the mechanically ventilated group tended to have higher cytokine mRNA expression than did the CPAP group. This lack of difference may result from the small number of lambs in each study group. The findings of more neutrophils and hydrogen peroxide is consistent with the initiation of more injury with mechanical ventilation as both indicators are early changes that occur with ventilator-induced lung injury (38). The CPAP lambs and conventionally ventilated lambs had similar wet to dry lung weights, amounts of protein in alveolar lavages, and surfactant pool sizes. Nevertheless, lung compliance as evaluated by the pressure-volume curves was better for the CPAP lambs. Pos- sible explanations are that inflation was more uniform and complete in the lambs exposed to $2 \mathrm{~h}$ of CPAP or that CPAP preserved surfactant function better than did mechanical ventilation. Ventilation can degrade surfactant function (39), and an unanswered question is whether CPAP more effectively preserves surfactant function.

The amount of inflammation that occurred with the initiation of ventilation by mechanical ventilation is less than we previously reported in more immature preterm lambs that were treated with surfactant (15). A probable explanation is that endogenous surfactant more effectively minimizes regional overdistension than does surfactant treatment because of the uniformity of distribution of the endogenous surfactant. The antenatal glucocorticoids also may have suppressed the inflammatory response of the fetal lung. Another possibility is that the higher $\mathrm{PCO}_{2}$ and associated respiratory acidosis may have minimized inflammation in the CPAP group. Although using much higher $\mathrm{PCO}_{2}$ values, Laffey et al. (40) found that elevated $\mathrm{CO}_{2}$ protected the isolated and perfused lung from reperfusion injury, and Broccard et al. (41) demonstrated similar effects on inflammation with ventilation-induced injury. This study demonstrates that CPAP can be studied in preterm lambs and indicates that CPAP induces less of an initial inflammatory response in the preterm lung than does mechanical ventilation to normal $\mathrm{P}_{\mathrm{CO}_{2}}$ values.

Acknowledgments. The authors thank Drs. John Smythe and David Sweet for helping us care for the animals.

\section{REFERENCES}

1. Soll RF, Morley C 2001 Prophylactic versus selective use of surfactant for preventing morbidity and mortality in preterm infants. The Cochrane Library, Issue 2. Oxford: Update Software

2. Crowley P 1995 Antenatal corticosteroid therapy: a meta-analysis of the randomized trials-1972-1994. Am J Obstet Gynecol 173:322-335

3. Clark RH, Gerstmann DR, Jobe AH, Moffitt ST, Slutsky AS, Yoder B A 2001 Lung injury in neonates: causes, strategies for prevention, and long- term consequences. J Pediatr 139:478-484

4. Gregory GA, Kitterman JA, Phibbs RH, Tooley WA, Hamilton WK 1971 Treatment of the idiopathic respiratory distress system with continuous positive airway pressure. N Engl J Med 284:1333-1340

5. Ho JJ, Subramaniam P, Henderson-Smart DJ, Davis P G 2001 Continuous distending pressure for respiratory distress syndrome in preterm infants. The Cochrane Library, Issue 2. Oxford: Update Software

6. Jobe A, Bancalari E 2001 NICHD/NHLBI/ORD workshop summary-bronchopulmonary dysplasia. Am J Respir Crit Care Med 163:1723-1729

7. Avery ME, Tooley WH, Keller JB, Hurd SS, Bryan MH, Cotton RB 1987 Is chronic lung disease in low birth weight infants preventable? A survey of eight centers. Pediatrics 79:26-30

8. Van Marter LJ, Allred EN, Pagano M, Sanocka U, Parad R, Moore M, Susser M, Paneth N, Leviton A 2000 Do clinical markers of barotrauma and oxygen toxicity explain interhospital variation in rates of chronic lung disease? Pediatrics 105:11941201

9. Lindner W, Vossbeck S, Hummler H, Pohlandt F 1999 Delivery room management of extremely low birth weight infants: spontaneous breathing or intubation? Pediatrics 103:961-967

10. Gittermann MK, Fusch C, Gittermann AR, Regazzoni BM, Moessinger AC 1997 Early nasal continuous positive airway pressure treatment reduces the need for intubation in very low birth weight infants. Eur J Pediatr 156:384-388

11. Albertine KH, Jones GP, Starcher BC, Bohnsack JF, Davis PL, Cho S, Carlton DP, Bland RD 1999 Chronic lung injury in preterm lambs. Am J Respir Crit Care Med 159:945-958

12. Jobe AH 1999 The new BPD: an arrest of lung development. Pediatr Res 46:641-643

13. Coalson JJ 2000 Pathology of chronic lung disease of early infancy. In: Bland RD, Coalson JJ (eds) Chronic Lung Disease in Early Infancy. Marcel Dekker, New York, pp $85-124$

14. Thibeault DW, Mabry SM, Ekekezie I, Truog W E 2000 Lung elastic tissue maturation and perturbations during the evolution of chronic lung disease. Pediatrics 106:1452-1459 
15. Naik AS, Kallapur SG, Bachurski CJ, Jobe AH, Michna J, Kramer BW, Ikegami M 2001 Effects of ventilation with different positive end-expiratory pressures on cytokine expression in the preterm lamb lung. Am J Respir Crit Care Med 164:494-498

16. Silver M, Fowden AL 1991 Induction of labour in sheep by inhibition of 3-beta hydroxysteroid dehydrogenase: role of the fetal adrenal. J Dev Physiol 15:169-174

17. Davey MG, Moss TJ, McCrabb GJ, Harding R 1996 Prematurity alters hypoxic and hypercapnic ventilatory responses in developing lambs. Respir Physiol 105:57-67

18. Michna J, Jobe AH, Ikegami M 1999 Positive end-expiratory pressure preserves surfactant function in preterm lambs. Am J Respir Crit Care Med 160:634-639

19. Jobe A, Ikegami M, Jacobs H, Jones S, Conaway D 1983 Permeability of premature lamb lungs to protein and the effect of surfactant on that permeability. J Appl Physiol 55:169-176

20. Kramer BW, Moss T, Willet K, Newnham J, Sly P, Kallapur SG, Ikegami M, Jobe A 2001 Dose and time response after intra-amniotic endotoxin in preterm lambs. Am J Respir Crit Care Med 164:982-988

21. Lowry OH, Rosebrough NJ, Farr AL, Randall RJ 1951 Protein measurement with the Folin phenol reagent. J Biol Chem 193:265-275

22. Kallapur SG, Willet KE, Jobe AH, Ikegami M, Bachurski C 2001 Intra-amniotic endotoxin: chorioamnionitis precedes lung maturation in preterm lambs. Am J Physiol 280:L527-L536

23. Mason RJ, Nellenbogen J, Clements JA 1976 Isolation of disaturated phosphatidylcholine with osmium tetroxide. J Lipid Res 17:281-284

24. Bartlett GR 1959 Phosphorus assay in column chromatography. J Biol Chem 234:466-468

25. Willet K, Jobe A, Ikegami M, Brennan S, Newnham J, Sly P 2000 Antenatal endotoxin and glucocorticoid effects on lung morphometry in preterm lambs. Pediatr Res 48:782-788

26. Verder H, Albertsen P, Ebbesen F, Greisen G, Robertson B, Bertelsen A, Agertoft L, Djernes B, Nathan E, Reinholdt J 1999 Nasal continuous positive airway pressure and early surfactant therapy for respiratory distress syndrome in newborns of less than 30 weeks' gestation. Pediatrics 103:E24

27. Poets CF, Sens B 1996 Changes in intubation rates and outcome of very low birth weight infants: a population-based study. Pediatrics 98:24-27

28. Garland JS, Buck RK, Allred EN, Leviton A 1995 Hypocarbia before surfactant therapy appears to increase bronchopulmonary dysplasia risk in infants with respiratory distress syndrome. Arch Pediatr Adolesc Med 149:617-622
29. Wada K, Jobe AH, Ikegami M 1997 Tidal volume effects on surfactant treatment responses with the initiation of ventilation in preterm lambs. J Appl Physiol 83:10541061

30. Coalson JJ, Winter VT, Siler-Khodr T, Yoder BA 1999 Neonatal chronic lung disease in extremely immature baboons. Am J Respir Crit Care Med 160:1333-1346

31. Jobe AH, Ikegami M 1998 Mechanisms initiating lung injury in the preterm. Early Hum Dev 53:81-94

32. Carlton DP, Albertine KH, Cho SC, Lont M, Bland RD 1997 Role of neutrophils in lung vascular injury and edema after premature birth in lambs. J Appl Physiol 83:1307-1317

33. Wung JT 1993 Respiratory management for low-birth-weight infants. Crit Care Med 21(suppl):S364-S365

34. Yoon BH, Romero R, Kim KS, Park JS, Ki SH, Kim BI, Jun JK 1999 A systemic fetal inflammatory response and the development of bronchopulmonary dysplasia. Am J Obstet Gynecol 181:773-779

35. Jobe AH, Ikegami M, Jacobs HC, Jones SJ 1983 Surfactant pool sizes and severity of respiratory distress syndrome in prematurely delivered lambs. Am Rev Respir Dis 127:751-755

36. Ikegami M, Kallapur S, Michna J, Jobe A H 2000 Lung injury and surfactant metabolism after hyperventilation of premature lambs. Pediatr Res 47:1-7

37. Jacobs H, Jobe A, Ikegami M, Jones S 1985 Accumulation of alveolar surfactant following delivery and ventilation of premature lambs. Exp Lung Res 8:125-140

38. Tremblay LN, Slutsky AS, Dreyfuss D, Saumon G 1998 Ventilator-induced lung injury: mechanisms and clinical correlates. In: Marini JJ, Slutsky AS (eds) Physiological Basis of Ventilatory Support. Marcel Dekker, New York, pp 395-451

39. Ito Y, Veldhuizen RAW, Yao L-J, McCaig A, Bartlett AJ, Lewis JF 1997 Ventilation strategies affect surfactant aggregate conversion in acute lung injury. Am J Respir Crit Care Med 155:493-499

40. Laffey JG, Tanaka M, Engelberts D, Luo X, Yuan S, Tanswell AK, Post M, Lindsay T, Kavanagh BP 2000 Therapeutic hypercapnia reduces pulmonary and systemic injury following in vivo lung reperfusion [In Process Citation]. Am J Respir Crit Care Med 162:2287-2294

41. Broccard AF, Hotchkiss JR, Vannay C, Markert M, Sauty A, Feihl F, Schaller MD 2001 Protective effects of hypercapnic acidosis on ventilator-induced lung injury. Am J Respir Crit Care Med 164:802-806 